\title{
Bilastine: new insight into antihistamine treatment
}

\author{
Erminia Ridolo ${ }^{1 *}$, Marcello Montagni ${ }^{1}$, Laura Bonzano ${ }^{1}$, Cristoforo Incorvaia $^{2}$ and Giorgio Walter Canonica ${ }^{3}$
}

\begin{abstract}
Bilastine is a new second generation $\mathrm{H1}$-antihistamine recently approved for the symptomatic treatment of allergic rhinitis (AR) and chronic urticaria (CU). Bilastine epitomizes the evolution of research on antihistamines concerning both efficacy and safety. In AR treatment, a number of large controlled clinical trials documented its efficacy, as assessed by improvement of all nasal and ocular symptoms and quality of life. These outcomes show that bilastine meets current EAACI/ARIA criteria for medications used in the treatment of AR. Also in CU, the review of the literature indicates that once-daily treatment with bilastine $20 \mathrm{mg}$ was effective in managing symptoms and improving patient's quality of life. Concerning safety and tolerability, the profile of bilastine is very similar to placebo and in particular the adverse effects on central nervous system are insignificant. The balance of efficacy and safety of bilastine is particularly helpful when dosages higher than standard are needed to control the symptoms, as frequently occurs in patients with urticaria, in whom antihistamines doses up to four times the standard dose may be administered.
\end{abstract}

Keywords: Antihistamines, Bilastine, Allergic rhinitis, Chronic urticaria, Efficacy, Safety

\section{Introduction}

Bilastine is a new second generation $\mathrm{H} 1$-antihistamine recently approved for the symptomatic treatment of allergic rhinitis (AR) and chronic urticaria (CU) in patients older than 12 years of age. AR and urticaria are very common clinical conditions that represent one of the most frequent reasons for a patient to visit their general practitioner or allergist. In the European countries $18 \%$ of population is suffering from AR [1] and in the United States AR affects a range of $10-30 \%$ of adults and up to $40 \%$ of children [2]. For urticaria, the life-time prevalence is approximately $20 \%$ for acute urticaria and $1.8 \%$ for $\mathrm{CU}$ [3]. These two clinical entities, though they have different and distinct characteristics, both cause a significant impairment of quality of life (QoL) and loss of productivity [4-6]. AR and urticaria respond to antihistamine treatment and current international guidelines recommend nonsedating second generation antihistamines as first line treatment for both $[3,7,8]$.

The role of histamine in allergic inflammation is unequivocal. It exerts its biological effects acting on four distinct receptors, but among them the H1-receptor plays the most important role in allergic diseases. H1-

\footnotetext{
* Correspondence: erminia.ridolo@unipr.it

${ }^{1}$ Department of Clinical and Experimental Medicine, University of Parma, via Gramsci 14, Parma 43126, Italy

Full list of author information is available at the end of the article
}

antihistamines can control allergic inflammation by directly interfering with histamine action at $\mathrm{H} 1$ receptors [9]. Based on their ability to cross the blood-brain barrier, H1-antihistamines are classified into 2 groups: the first generation antihistamines that bind the H1receptors on neurons in the central nervous system, causing sedation and impaired mental status, and the second-generation antihistamines (including bilastine) that usually cannot cross the blood-brain barrier and thus have fewer sedative effects. The long duration of action, efficacy, low-sedation impact and low-performance impairment of second generation antihistamines, and particularly of bilastine, make it a potentially attractive therapeutic option for allergists.

This review focuses on the clinical characteristics of bilastine and the evidence of its efficacy in the treatment of AR and urticaria.

\section{Review}

Pharmacodynamic and pharmacokinetic properties

From a molecular point of view, bilastine is 2-[4-(2-(4(1-(2- ethoxyethyl)-1Hbenzimidazol-2-yl) piperidin-1-yl) ethyl) phenyl]-2-methyl propionic acid. It belongs to piperidine derivatives and is not structurally derived from any other currently available antihistamines. Bilastine exerts a potent and specific H1-antihistamine activity. 
Bilastine is an $\mathrm{H} 1$ receptor inverse agonist, like other antihistamines already available. Preclinical in vitro studies showed that bilastine has high specificity for H1-receptors while has negligible affinity for 30 other receptors (serotonin, bradykinin, leukotriene-D4, muscarinic M3-receptors, $\alpha 1$-adrenoceptors, $\beta 2$-adrenoceptors, and H2- and H3histamine receptors) [10]. The affinity for the $\mathrm{H} 1$ receptor is 3 and 6 times higher than for cetirizine and fexofenadine, respectively. The results of in vivo preclinical studies confirmed those obtained from in vitro experiments, as in rats bilastine has demonstrated to reduce histaminestimulated smooth muscular contraction, bronchospasms, endothelial permeability, and microvascular extravasation, providing evidence to possess antiallergic properties, with similar potency to cetirizine and superior potency to fexofenadine [11].

In vitro data have shown that bilastine also exerts antiinflammatory activity by inhibiting the release of histamine, IL-4 and tumor necrosis factor (TNF)- $\alpha$ from human mast cells and granulocytes [12].

The drug is rapidly absorbed after oral administration with a time to maximum plasma concentration of around 1 hour following administration [13]. The mean value of bilastine oral bioavailability was found to be about $60 \%$ [14]. The maximum plasma concentration $(220 \mathrm{ng} / \mathrm{mL})$ of bilastine $20 \mathrm{mg}$ was detected 1.3 hours after administration, the half time was 14.5 hours, and plasma protein binding was $84-90 \%[13,14]$. Bilastine does not undergo any significant hepatic metabolism and approximately $95 \%$ is excreted intact in faeces $(67 \%)$ or in urine (33\%); bilastine is a substrate for P-glycoprotein which limits its passage across the blood-brain barrier [15], and not clinically relevant interactions have been reported to date. The mean elimination half-life calculated in healthy volunteers was $14.5 \mathrm{~h}$ and the apparent total plasma clearance is $18.1 \mathrm{~L} / \mathrm{h}[16,17]$. Bilastine is not a substrate of CYP450 family [18].

\section{Efficacy of bilastine Wheal and flare inhibition}

A phase 1, double-blind, randomised, placebo-controlled, single oral dose, cross-over study compared the antihistaminic effects of bilastine, cetirizine and placebo against histamine-induced wheal and flare responses, over periods of $24 \mathrm{~h}$, in 21 healthy male volunteers [19]. In that trial, volunteers were randomised to receive single oral doses of bilastine 20 or $50 \mathrm{mg}$, cetirizine $10 \mathrm{mg}$ or placebo before provocation of wheal and flare responses to $100 \mathrm{mg} / \mathrm{ml}$ histamine by skin prick 1.5, 4, 8, 12 and 24 h later. The authors found no significant differences between overall inhibitions of wheal or flare by bilastine $20 \mathrm{mg}$ and cetirizine10 mg but bilastine was faster in onset of action than cetirizine, inhibition of wheal and flare at $1.5 \mathrm{~h}$ being $89 \pm 3$ versus $44 \pm 14 \%(\mathrm{P}=0.011)$ and $85 \pm 4$ versus
$45 \pm 14 \% \quad(P=0.016)$, respectively. At $1.5 \mathrm{~h}$, both wheals and flares were inhibited by $70 \%$ in $11 / 12$ volunteers taking bilastine and $3 / 11$ taking cetirizine $(\mathrm{P}=0.003)$. There were no significant differences between the drugs at later times.

\section{Bilastine efficacy in allergic rhinitis}

Efficacy of bilastine was well recognized in both seasonal and perennial allergic rhinitis. The Vienna Challenge Chamber is an established standardized method for the controlled exposure of patients to defined allergens, that is used to make comparisons between different antihistamines $[20,21]$. Using this method, a double blind, randomized, placebo controlled, balanced four-treatment, four-period crossover phase II study was conducted in patients suffering from seasonal AR (SAR) in order to compare the efficacy of bilastine, cetirizine and fexofenadine to relieve symptoms [22]. The study was conducted in adult patients with confirmed allergy to grass pollen, outside the pollen season while they were asymptomatic. Total Nasal Symptoms Score (TNSS) was used to compare the effect of a single dose of bilastine $20 \mathrm{mg}$, cetirizine $10 \mathrm{mg}$, fexofenadine $120 \mathrm{mg}$ and placebo administered two hours after the start of the challenge. During the first four hours after administration, all treatment were significantly more effective than placebo in reducing TNSS ( $<<0.001)$, without significant difference between the three antihistamines. Moreover, bilastine at $20 \mathrm{mg}$ was as effective as cetirizine $10 \mathrm{mg}$ and fexofenadine $120 \mathrm{mg}$ in terms of onset of action and in reducing eye symptoms $1 \mathrm{~h}$ after the intake. Bilastine was still effective 26 hours after the intake, confirming the prolonged duration of action.

The efficacy of bilastine in patients with SAR has also been evaluated in two double-blind, placebo-controlled studies, with the same design, evaluating parameters for efficacy and safety, including assessment of QoL in the first one, comparing once daily bilastine $20 \mathrm{mg}$ with placebo, desloratadine $5 \mathrm{mg}$ and cetirizine $10 \mathrm{mg}$ over two weeks $[23,24]$. Details of the two studies are provided in table 1 . These two studies enrolled a total of 1404 patients, aged between 12 and 70 years, with documented SAR due to pollen allergens. In both studies primary outcome measure of TSS was significantly reduced in the bilastine group significantly more than in the placebo group and to a similar extent as in the active comparator group (table 1). Also, bilastine improved QoL, measured by rhinoconjunctivitis quality of life questionnaire (RQLQ), to a similar extent than desloratadine; bilastine $20 \mathrm{mg}$ significantly improved total RQLQ score and most RQLQ single domains respect to placebo.

A multicenter, randomized, placebo-controlled, doubleblind, parallel-group study was conducted in 650 patients with symptomatic persistent AR (PAR) [25]. The authors found no significant differences in efficacy outcomes 
Table 1 Double blind randomized trials in seasonal AR

\begin{tabular}{|c|c|c|c|c|c|}
\hline Study & Patients N. & Duration & Treatment & Efficacy & Safety vs active comparator \\
\hline Kuna P et al. [24] & 683 & 14 days & $\begin{array}{l}\text { Bilastine } 20 \mathrm{mg} \\
\text { Cetirizine } 10 \mathrm{mg} \\
\text { Placebo }\end{array}$ & $\begin{array}{l}\text { The mean TSS-AUC }{ }_{0 \_}{ }_{14} \text { days (score_day) } \\
\text { was reduced in bilastine and cetirizine } \\
\text { groups to a similar and significantly } \\
\text { greater extent, compared with placebo } \\
(\mathrm{P}<0.001) \text {. Bilastine and cetirizine were } \\
\text { comparable and significantly superior } \\
\text { to placebo for all secondary outcomes }\end{array}$ & $\begin{array}{l}\text { Significantly fewer patients in the } \\
\text { bilastine-treated group experienced } \\
\text { somnolence }(P<0.001) \text { and fatigue } \\
(P=0.02) \text { than patients in the } \\
\text { cetirizine-treated group. }\end{array}$ \\
\hline Bachert C et al. [23] & 721 & 14 days & $\begin{array}{l}\text { Bilastine } 20 \text { mg } \\
\text { Desloratadine } 5 \\
\text { mg Placebo }\end{array}$ & $\begin{array}{l}\text { The AUC of TSS was decreased to a } \\
\text { significantly greater extent in the } \\
\text { bilastine group compared with } \\
\text { placebo group }(P<0.001) \text {. Total RQLQ } \\
\text { score was significantly reduced from } \\
\text { baseline by a value of } 1.6(1.2 ; 1.8-1.4) \\
\text { in the bilastine treated group compared } \\
\text { with a value of } 1.3(1.3 ; 1.5-1.1) \text { in the } \\
\text { placebo-treated group }(P<0.005)\end{array}$ & $\begin{array}{l}\text { Safety profile of bilastine and } \\
\text { desloratadine were comparable } \\
\text { to placebo. }\end{array}$ \\
\hline
\end{tabular}

TSS-AUC $_{0 \_14}$ : area under the curve (AUC) of the reflective total symptoms score (TSS) from day 0 (D0) today 14; RQLQ: rhinoconjunctivitis quality of

life questionnaire.

between active treatments and placebo in the overall population, over 4 weeks of treatment, but in the post-hoc analysis bilastine $20 \mathrm{mg}$ was more effective than placebo and as effective as cetirizine $10 \mathrm{mg}$ the population of patients from Europe and Argentina, while the difference remained not statistically significant in patients from South Africa. The lack of efficacy through the whole group was likely to be due to the group great variability of symptom scores reported in different countries, particularly in South Africa [26].

Davila et al. and Bartra et al. analyzed the data about the effect of bilastine upon nasal obstruction and ocular symptoms from 7 phase II and phase III 2-4 weeks duration clinical trials $[27,28]$. Mean change from baseline in nasal obstruction symptoms score after two weeks of treatment was -0.66 with bilastine $20 \mathrm{mg}$ and -0.57 with placebo $(\mathrm{p}<0.001$ ), active comparators (cetirizine $10 \mathrm{mg}$ and desloratadine $5 \mathrm{mg}$ ) induced a reduction of -0.67 points ( $\mathrm{p}<0.001$ vs placebo; not statistically different vs bilastine) [27]. Similarly, bilastine was more effective in ocular symptoms relief than placebo and as effective as active comparators [28].

\section{Bilastine efficacy in urticaria}

A multi-centre, double-blind, randomized, placebocontrolled study compared the efficacy and safety of bilastine $20 \mathrm{mg}$ vs levocetirizine $5 \mathrm{mg}$ for the treatment of chronic idiopathic urticaria in 525 adult patients [29]. The TSS was reduced progressively by all treatments from baseline over a period of 28 days treatment, with significant differences noted between bilastine $20 \mathrm{mg}$ and levocetirizine $5 \mathrm{mg}$-treated groups vs placebo-treated group from day 2 onward over the entire treatment period. The mean change from baseline in the patients' reflective daily TSS over the 28-day treatment period, that was the primary efficacy measure, was significantly greater for bilastine $20 \mathrm{mg}$ and levocetirizine $5 \mathrm{mg}$ treated groups compared with placebo-treated group $(\mathrm{P}<0.001$ for bilastine and levocetirizine vs placebo), but not significantly different between the active treatment groups.

Cold urticaria is a quite uncommon form of inducible urticaria, characterized by pruritic wheals and/or angioedema due to cutaneous mast cell activation and release of pro-inflammatory mediators after cold exposure [30]. Reduction of symptoms in many patients with cold urticaria requires high dosing with antihistamines, up to four times the daily recommended dose [31,32]. Krause et al. assessed the effects of the standard $20 \mathrm{mg}$ dose and updosing to 40 and $80 \mathrm{mg}$ of bilastine in reducing the symptoms of $\mathrm{CU}$ and inflammatory mediator release following cold challenge in a randomized, crossover, double-blind, placebo-controlled 12-week study [33]. In this study patients suffering from cold urticaria, confirmed by a specific provocation test, received placebo, 20, 40 or $80 \mathrm{mg}$ of bilastine daily each for 7 days with 14-day washout periods. Bilastine was effective already at routine doses: in patients receiving $20 \mathrm{mg}$, the critical temperature threshold (CCT, the highest temperature that produces a positive wheal response) was significantly different from placebo (the median CCT value was $6^{\circ} \mathrm{C}$ in bilastine group and $18^{\circ} \mathrm{C}$ in placebo group), $\mathrm{P}<0.0001$ ), as well as the number of patients that became symptom free $(\mathrm{P}=0.044)$. The up-dosing was beneficial, since the median CTT with bilastine $80 \mathrm{mg}$ was significantly lower than that of $20 \mathrm{mg}(\mathrm{P}=0.003)$ and $40 \mathrm{mg}(\mathrm{P}=0.04)$. Moreover, inflammatory mediators were significantly reduce by bilastine $80 \mathrm{mg}$.

\section{Safety of bilastine}

Tolerability data from the four phase III trials of 2-4 weeks duration are summarized in table 2 . In these studies, bilastine was well tolerated and the majority of the 
Table 2 AEs in patients receiving bilastine $20 \mathrm{mg}$ in clinical trials

\begin{tabular}{|c|c|c|c|}
\hline Study & $\begin{array}{l}\text { Patients } \\
\text { N. Duration }\end{array}$ & Disease & $\begin{array}{l}\text { AEs in bilastine- } \\
\text { treated group }\end{array}$ \\
\hline \multirow[t]{6}{*}{ Kuna P et al. [24] } & 683 & SAR & Any $24.7 \%$ \\
\hline & 14 days & & \\
\hline & & & Headache 10.6\% \\
\hline & & & Somnolence $1.8 \%$ \\
\hline & & & Fatigue $0.4 \%$ \\
\hline & & & Dyspnoea 0.9\% \\
\hline \multirow[t]{4}{*}{ Bachert C et a. [23] } & 721 & SAR & Any $28.3 \%$ \\
\hline & 14 days & & Headache 12.0\% \\
\hline & & & Somnolence 3.9\% \\
\hline & & & Fatigue $2.6 \%$ \\
\hline \multirow[t]{4}{*}{ Sastre J et al. [25] } & 650 & PAR & Any $23.4 \%$ \\
\hline & 4 weeks & & \\
\hline & & & Headache 10.7\% \\
\hline & & & Somnolence $13.7 \%$ \\
\hline \multirow[t]{4}{*}{ Zuberbiert T et al. [29] } & 525 & $\mathrm{CIU}$ & Any $30.1 \%$ \\
\hline & 28 days & & Headache $12.1 \%$ \\
\hline & & & Somnolence 5.8\% \\
\hline & & & Fatigue $2.9 \%$ \\
\hline
\end{tabular}

SAR: seasonal allergic rhinitis; PAR: persistent allergic rhinitis, CIU: chronic idiopatic urticarial, AEs: adverse event.

adverse events described were either mild or moderate, while no serious adverse events or death were reported; moreover, there were no clinically significant changes in any laboratory tests, ECGs, heart rate, or systolic and diastolic blood pressure, in patients treated with bilastine $20 \mathrm{mg}$. The most common adverse effects were headache, somnolence and fatigue that were reported less frequently than in patients receiving cetirizine at $10 \mathrm{mg}$ once daily. The frequency of these adverse effects in patients with SAR were comparable with that of desloratadine. The first generation antihistamines cross the blood-brain barrier and bind the H1-receptors on postsynaptic neurons membranes in the central nervous system, causing sedation and impaired mental status, while the second-generation antihistamines usually do not cross the blood-brain barrier and have fewer sedative effects. Bilastine $20 \mathrm{mg}$ histamine H1-receptor occupancy had been evaluated by positron emission tomography (PET) in healthy subjects, confirming that bilastine has objective and PET criteria to be defined as a non-sedating antihistamine [34]. Moreover, bilastine demonstrated to produce only very little or even no performance impairment. In a crossover, randomized, double-blind, placebo-controlled study 20 healthy volunteers received repeated doses of bilastine 20 , 40 , or $80 \mathrm{mg}$ and first generation antihistamine hydroxyzine $25 \mathrm{mg}$ on 7 consecutive days [35]. Bilastine in doses up to $40 \mathrm{mg}$ did not produce psychomotor impairment as compared with placebo, even if $40 \mathrm{mg}$ produced subjective report of sedation, and an objective impairment was only evident at bilastine doses of $80 \mathrm{mg}$. Similarly, bilastine did not produce any driving impairment after single and repeated doses up to $40 \mathrm{mg}$ [36]. At the therapeutic dose of $20 \mathrm{mg}$ the concomitant administration of bilastine and alcohol does not produce greater central nervous system (CNS) depressant effects than alcohol alone, while objective impairment induced bilastine $80 \mathrm{mg}+$ alcohol $(0.8 \mathrm{~g} / \mathrm{Kg})$ was of similar magnitude to that induced by hydroxyzine $25 \mathrm{mg}+$ alcohol [37]. Also cardiac safety was confirmed at therapeutic and supratherapeutic doses. Bilastine administration at $20 \mathrm{mg}$ and $100 \mathrm{mg}$ had no clinically significant impact on QTc. Concomitant administration of ketoconazole and bilastine $20 \mathrm{mg}$ induced a clinically relevant increase in QTc but this result was most likely related to the cardiac effect of ketoconazole [38]. Moreover, bilastine, at therapeutic and supratherapeutic dosages (up to $100 \mathrm{mg}$ ), did not induce any effects on T-wave morphology [39].

\section{Conclusions}

Bilastine epitomizes the evolution of research on antihistamines concerning both efficacy and safety [40]. In AR treatment, its efficacy has been documented in several large controlled clinical trials [26]. Bousquet et al. in 2012 reviewed the available literature and found that bilastine $20 \mathrm{mg}$ once daily improved all nasal and ocular symptoms of AR and improved quality of life, an important outcome in allergic diseases. Therefore, the authors concluded that bilastine meets current EAACI/ARIA criteria for medications used in the treatment of AR [41]. In a comparable review of the medical literature on the effectiveness of bilastine in urticarial syndromes, either spontaneous or inducible, Jauregui et al. concluded that once-daily treatment with bilastine $20 \mathrm{mg}$ was effective in managing symptoms and improving patient's quality of life in chronic urticaria [42]. Concerning safety and tolerability, the profile of bilastine is very similar to placebo in all Phase I, II and III clinical trials. Differently from most antihistamines, bilastine does not increase the CNS depressant effect of lorazepam and, unlike other second-generation antihistamines such as cetirizine, does not increase alcohol effects on the CNS [43]. The balance of efficacy and safety of bilastine is particularly helpful when dosages higher than standard are needed to control the symptoms. This is of particular importance when the doses are much higher, as frequently occurs in patients with urticaria, where antihistamines doses up to four times the standard dose are administered, patient safety being a key requirement when choosing a specific antihistamine [44]. 


\section{Competing interests}

The authors declare that they have no competing interests.

\section{Authors' contributions}

All authors have contributed equally to the the writing of the manuscript. All authors read and approved the final manuscript.

\section{Acknowledgements}

Partially supported by ARMIA - Associazione Ricerca Malattie Immunologiche ed Allergiche - Genova

\section{Author details}

${ }^{1}$ Department of Clinical and Experimental Medicine, University of Parma, via Gramsci 14, Parma 43126, Italy. ²Pulmonary Rehabilitation Unit, ICP Hospital, Milan, Italy. ${ }^{3}$ Allergy and Respiratory Diseases Clinic, DIMI, University of Genoa, IRCCS AOU San Martino-IST, Genoa, Italy.

\section{Received: 13 January 2015 Accepted: 19 February 2015}

\section{Published online: 15 April 2015}

\section{References}

1. Bousquet J, Van Cauwenberge P, Khaltaev N, ARIA Workshop Group. World health organization. Allergic rhinitis and its impact on asthma. J Allergy Clin Immunol. 2001;108(5 Suppl):S147-334.

2. Dykewicz MS, Fineman S. Executive summary of joint task force practice parameters on diagnosis and management of rhinitis. Ann Allergy Asthma Immunol. 1998;81:463-8.

3. Zuberbier T, Aberer W, Asero R, Bindslev-Jensen C, Brzoza Z, Canonica GW, et al. The EAACI/GA (2) LEN/EDF/WAO Guideline for the definition, classification, diagnosis, and management of urticaria: the 2013 revision and update. Allergy. 2014;69(7):868-87.

4. Kakumanu S, Glass C, Craig T. Poor sleep and daytime somnolence in allergic rhinitis: significance of nasal congestion. Am J Respir Med. 2002;1 (3):195-200.

5. Thompson AK, Juniper E, Meltzer EO. Quality of life in patients with allergic rhinitis. Ann Allergy Asthma Immunol. 2000;85:338-47.

6. Weldon D. Quality of life in patients with urticaria and angioedema: assessing burden of disease. Allergy Asthma Proc. 2014;35(1):4-9.

7. Bousquet J, Khaltaev N, Cruz AA, Denburg J, Fokkens WJ, Togias A, et al. Allergic rhinitis and its impact on asthma (ARIA) 2008 update. Allergy. 2008;63 Suppl 86:8-160.

8. Meltzer EO, Bukstein DA. The economic impact of allergic rhinitis and current guidelines for treatment. Ann Allergy Asthma Immunol. 2011;106(2Suppl):S12-6.

9. Simons FE, Simons KJ. Histamine and H1-antihistamines: celebrating a century of progress. J Allergy Clin Immunol. 2011;128(6):1139-1150.e4.

10. Corcóstegui R, Labeaga L, Innerárity A, Berisa A, Orjales A. Preclinical pharmacology of bilastine, a new selective histamine $\mathrm{H} 1$ receptor antagonist: receptor selectivity and in vitro antihistaminic activity. Drugs R D. 2005;6(6):371-84.

11. Corcóstegui R, Labeaga L, Innerárity A, Berisa A, Orjales A. In vivo pharmacological characterisation of bilastine, a potent and selective histamine $\mathrm{H} 1$ receptor antagonist. Drugs R D. 2006;7(4):219-31.

12. Alvarez-Mon M, San Antonio E, Lucero M, Sanz E, Ledo F, De la Hera A. Bilastine, a novel antihistamine that preferentially inhibits histamine and interleukin-4 release from human mast cells and granulocytes. Allergy. 2009;64 Suppl 90:555.

13. Jauregizar N, de la Fuente L, Lucero ML, Sologuren A, Leal N, Rodríguez M. Pharmacokinetic-pharmacodynamic modelling of the antihistaminic $(\mathrm{H} 1)$ effect of bilastine. Clin Pharmacokinet. 2009;48(8):543-54.

14. Sádaba B, Gómez-Guiu A, Azanza JR, Ortega I, Valiente R. Oral availability of bilastine. Clin Drug Investig. 2013;33(5):375-81.

15. Lucero ML, Gonzalo A, Ganza A, Leal N, Soengas I, loja E, et al. Interactions of bilastine, a new oral $\mathrm{H}(1)$ antihistamine, with human transporter systems. Drug Chem Toxicol. 2012;35 Suppl 1:8-17.

16. Lucero ML, Gonzalo A, Mumford R, Betanzos M, Alejandro A. An overview of bilastine metabolism during preclinical investigations. Drug Chem Toxicol. 2012;35 Suppl 1:18-24.

17. Sologuren A, Lucero ML, Valiente R, Valiente R, Charles H, Mair SJ. Human mass balance with [14C]-bilastine following oral administration to healthy volunteers. Basic Clin Pharmacol Toxicol. 2009;105 Suppl 1:106-7.

18. Lucero ML, Orjales A, Morag N. In vitro hepatic metabolism of [14C]-bilastine. suppl I. 2007;39:114.
19. Church MK. Comparative inhibition by bilastine and cetirizine of histamine-induced wheal and flare responses in humans. Inflamm Res. 2011;60(12):1107-12.

20. Horak F, Jager S. Wiener Provokations-Kammer (Vienna challenge chamber): eine neue Methode des Allergenexpositionstests. Wiener klin Wochenschr. 1987;99:509-10.

21. Stübner P, Zieglmayer R, Horak F. A direct comparison of the efficacy of antihistamines in SAR and PAR: randomised, placebo-controlled studies with levocetirizine and loratadine using an environmental exposure unit - the Vienna challenge chamber (VCC). Curr Med Res Opin. 2004;20(6):891-902.

22. Horak F, Zieglmayer P, Zieglmayer R, Lemell P. The effects of bilastine compared with cetirizine, fexofenadine, and placebo on allergen-induced nasal and ocular symptoms in patients exposed to aeroallergen in the Vienna challenge chamber. Inflamm Res. 2010;59(5):391-8.

23. Bachert C, Kuna P, Sanquer F, Ivan P, Dimitrov V, Gorina MM, et al. Comparison of the efficacy and safety of bilastine $20 \mathrm{mg}$ vs desloratadine $5 \mathrm{mg}$ in seasonal allergic rhinitis patients. Allergy. 2009;64:158-65.

24. Kuna P, Bachert C, Nowacki Z, van Cauwenberge P, Agache I, Fouquert L, et al. Efficacy and safety of bilastine $20 \mathrm{mg}$ compared with cetirizine $10 \mathrm{mg}$ and placebo for the symptomatic treatment of seasonal allergic rhinitis: A randomized, double-blind, parallelgroup study. Clin Exp Allergy. 2009;39:1338-47.

25. Sastre J, Mullol J, Valero A, Valiente R, Bilastine Study Group. Efficacy and safety of bilastine $20 \mathrm{mg}$ compared with cetirizine $10 \mathrm{mg}$ and placebo in the treatment of perennial allergic rhinitis. Curr Med Res Opin. 2012;28(1):121-30.

26. Kowal K, DuBuske L. Bilastine as a potential treatment in allergic rhinitis. Am J Rhinol Allergy. 2014;28(4):312-6.

27. Dávila I, Sastre J, Mullol J, Montoro J, Jáuregui I, Ferrer M, et al. Effect of bilastine upon nasal obstruction. J Investig Allergol Clin Immunol. 2011;21 Suppl 3:2-8.

28. Bartra J, Mullol J, Montoro J, Jáuregui I, del Cuvillos A, Dávila I, et al. Effect of bilastine upon the ocular symptoms of allergic rhinoconjunctivitis. J Investig Allergol Clin Immunol. 2011;21 Suppl 3:24-33.

29. Zuberbier T, Oanta A, Bogacka E, Medina I, Wesel F, Uhl P, et al. Comparison of the efficacy and safety of bilastine $20 \mathrm{mg}$ vs levocetirizine $5 \mathrm{mg}$ for the treatment of chronic idiopathic urticaria: a multi-centre, double-blind, randomized, placebo-controlled study. Allergy. 2010;65(4):516-28.

30. Siebenhaar F, Weller K, Mlynek A, Magerl M, Altrichter S, Vieira Dos Santos R, et al. Acquired cold urticaria: clinical picture and update on diagnosis and treatment. Clin Exp Dermatol. 2007;32(3):241-5

31. Magerl M, Pisarevskaja D, Staubach P, Martus P, Church MK, Maurer M. Critical temperature threshold measurement for cold urticaria: a randomized controlled trial of $\mathrm{H}$ (1) -antihistamine dose escalation. Br J Dermatol. 2012;166(5):1095.

32. Siebenhaar F, Degener F, Zuberbier T, Martus P, Maurer M. High-dose desloratadine decreases wheal volume and improves cold provocation thresholds compared with standard-dose treatment in patients with acquired cold urticaria: a randomized, placebo-controlled, crossover study. J Allergy Clin Immunol. 2009;123(3):672.

33. Krause K, Spohr A, Zuberbier T, Church MK, Maurer M. Up-dosing with bilastine results in improved effectiveness in cold contact urticaria. Allergy. 2013;68(7):921-8

34. Farré M, Pérez-Mañá C, Papaseit E, Menoyo E, Pérez M, Martin S, et al. Bilastine vs. hydroxyzine: occupation of brain histamine $\mathrm{H} 1$-receptors evaluated by positron emission tomography in healthy volunteers. $\mathrm{Br}$ J Clin Pharmacol. 2014;78(5):970-80.

35. García-Gea C, Martínez-Colomer J, Antonijoan RM, Valiente R, Barbanoj MJ. Comparison of peripheral and central effects of single and repeated oral dose administrations of bilastine, a new $\mathrm{H} 1$ antihistamine: a dose-range study in healthy volunteers with hydroxyzine and placebo as control treatments. J Clin Psychopharmacol. 2008;28(6):675-85.

36. Conen S, Theunissen EL, Van Oers AC, Valiente R, Ramaekers JG. Acute and subchronic effects of bilastine (20 and $40 \mathrm{mg}$ ) and hydroxyzine $(50 \mathrm{mg})$ on actual driving performance in healthy volunteers. J Psychopharmacol. 2011;25(11):1517-23.

37. García-Gea C, Martínez J, Ballester MR, Gich I, Valiente R, Antonijoan RM. Psychomotor and subjective effects of bilastine, hydroxyzine, and cetirizine, in combination with alcohol: a randomized, double-blind, crossover, and positive-controlled and placebo-controlled Phase I clinical trials. Hum Psychopharmacol. 2014;29(2):120-32.

38. Tyl B, Kabbaj M, Azzam S, Sologuren A, Valiente R, Reinbolt E, et al. Lack of significant effect of bilastine administered at therapeutic and 
supratherapeutic doses and concomitantly with ketoconazole on ventricular repolarization: results of a thorough QT study (TQTS) with QT-concentration analysis. J Clin Pharmacol. 2012;52(6):893-903.

39. Graff C, Struijk JJ, Kanters JK, Andersen MP, Toft E, Tyl B. Effects of bilastine on T-wave morphology and the QTC interval: a randomized, double-blind, placebo-controlled, thorough QTc study. Clin Drug Investig. 2012;32(5):339-51.

40. Sadaba B, Azanza JR, Gomez-Guiu A, Rodil R. Critical appraisal of bilastine for the treatment of allergic rhinoconjunctivitis and urticaria. Ther Clin Risk Manag. 2013;9:197-205.

41. Bousquet J, Ansótegui I, Canonica GW, Zuberbier T, Baena-Cagnani CE, Bachert C, et al. Establishing the place in therapy of bilastine in the treatment of allergic rhinitis according to ARIA: evidence review. Curr Med Res Opin. 2012:28(1):131-9.

42. Jauregui I, Ferrer M, Bartra J, del Cuvillo A, Davila I, Montoro J, et al. Bilastine for the treatment of urticaria. Expert Opin Pharmacother. 2013;14(11):1537-44.

43. Scaglione F. Safety profile of bilastine: 2 nd generation $\mathrm{H} 1$-antihistamines. Eur Rev Med Pharmacol Sci. 2012;16:1999-2005.

44. Zuberbier T. Pharmacological rationale for the treatment of chronic urticaria with second-generation non-sedating antihistamines at higher than standard doses. J Eur Acad Dermatol Venereol. 2012;26(1):9-18.

\section{Submit your next manuscript to BioMed Central and take full advantage of:}

- Convenient online submission

- Thorough peer review

- No space constraints or color figure charges

- Immediate publication on acceptance

- Inclusion in PubMed, CAS, Scopus and Google Scholar

- Research which is freely available for redistribution 